\title{
Modern education technologies: 21st century trends and challenges
}

\author{
Viktor Moshinski ${ }^{1, *}$, Nataliia Pozniakovska ${ }^{1, * *}$, Olesia Mikluha ${ }^{1, * * *}$, and Maksym Voitko $^{2, * * * *}$ \\ ${ }^{1}$ National University of Water and Environmental Engineering, 11 Soborna Str., Rivne, 33028, Ukraine \\ ${ }^{2}$ LLC “SOFT CONSTRACT UKRAINE”, 13/6 Mykoly Pymonenka Str., Kyiv, 04050, Ukraine
}

\begin{abstract}
Since modern technologies produce new global education trends, education prospects redesign, and new opportunities and threats assessments are needed. The new educational technology development phase was researched as an answer to modern world challenges. The strategic priorities of education in the EU are analyzed. New technologies, practices, and related needs: financing, digital integration, accessibility, informational security were studied and generalized. Higher education key trends and their transformation in the context of the COVID-19 crisis new opportunities and threats were researched. The analysis of the seven years of NMC Horizon and other research emerging educational technologies adoption forecasts provided in the research shows significant discrepancies related to extreme uncertainty. Five educational trend groups from the NMC Horizon report 2020 were reviewed. The author defined the remote education tools and their importance on the example of the university providing online/mixed learning. The anonymous polls among lecturers and students performed in the spring of 2020 (just after the COVID-19 quarantine announcement) show the most highly demanded tools are Google Meet, email, specific learning systems such as Moodle. The barriers to fullyfledged remote education are technical problems and occasionally poor Internet connectivity. The participants are quite ready to learn and to use digital tools for education. However, the absence of live communication increases workload during online learning, and other factors arise as the factors lowering student activity. During severe transformation, the main tasks of education are accessibility and diversity.
\end{abstract}

\section{Introduction}

Global challenges of the modern world should be answered with new ways of social development. The best scientists, industry leaders, and civil society actors empathize with the dominance of outdated philosophical doctrines and economic models in recognized world theories. Global Financial Stability Report describes the enormous uncertainty in all spheres [1], which is proved by the instant correction of the current year world economic growth rate forecast $[2,3]$.

In the Jubilee report, the Club of Rome concludes that to overcome old thinking leading to a catastrophe we need new enlightenment [4]. The authors of the report call to fundamentally transform the mindset resulting in holistic vision, an integral view of the world complexity based on a systematic approach. Innovative education should be a response to the current global challenges. Education was seriously transformed since the beginning of the century systems, forms, methods, and technologies were changed [5].

In the development concept of the digital economy and society of Ukraine for 2018-2020 [6] education digitalization was defined as the latest phase of education informatization [7] supposing informational and educa-

\footnotetext{
*e-mail: v.s.moshynskyi@nuwm.edu.ua

**e-mail: n.m.poznyakovska@nuwm.edu.ua

***e-mail: o.1.miklukha@nuwm.edu.ua

****e-mail: max.voitko@gmail.com
}

tional environment saturation with electronic digital devices, tools, systems, and electronic and communication exchange. The exchange enables integral interaction of the virtual and the physical, and so creates cyber-physical educational space.

Educational technologies development and usage in educational methodologies at the current stage of social development are addressed by S. Amelina [8], O. Bondarenko [9], O. Burov [10], V. Bykov [11], A. Gurzhii [12], A. Kiv [13], M. Kislova [14], T. Kramarenko [15], O. Lavrentieva [16], O. Markova [17], I. Mintii [18], Y. Modlo [19], N. Moiseienko [20] N. Morze [21], P. Nechypurenko [22], V. Osadchyi [23], N. Rashevska [24], S. Semerikov [25], S. Shokaliuk [26], M. Shyshkina [27], V. Soloviev [28], O. Spirin [29], A. Striuk [30], S. Sysoieva [31], I. Teplytskyi [32], V. Tkachuk [33], T. Vakaliuk [34], K. Vlasenko [35], N. Volkova [36], O. Yankovych [37], Y. Yechkalo [38] and others.

Scientists [39] believe educational technologies represent a common strategy of education and education consistency development. O. Yankovych, Y. Bednarek, and A. Andzheyevska highlight cross-cutting information technologies that span all groups of technologies used in educational and managerial processes and technologies [40, 41]. According to O. Topuzov, O. Malykhin, T. Yarmolchuk new information era requires an effective influence on professional personality development processes, which should change the mindset, and improve the 
innovative and creative potential of education applicants [42]. G. Kovalchuk specifies the main directions of higher and secondary education transformation in economy and business, implying the integration of education with industry and science, the transition from generalized to personalized education, creativity development [43].

V. Bykov [44] stressed the relevance of informational education development, ICT skills development in educational systems among students and citizens. This in turn requires new tasks for psychological and pedagogical science and educational practice.

In M. Kademiia's opinion, the research of the modern pedagogical technologies, ICT, ICM-technologies adoption in the educational process, and informational and educational environment creation gives a possibility to introduce electronic, mobile, pervasive, and life-long learning $[45,46]$.

I. Dychkivska noted the innovation in pedagogics related to overall processes in the society, global challenges, integrative knowledge, and social choice forms [47]. O. Tovkanets named the following strategic directions in ICT development in European countries: innovational pedagogical approaches, educational models and strategies development and testing; ICT adoption on all phases of education; creation of the open platform of IT, digital content, services, pedagogical concepts and approaches, motivation models, cloud technologies in educational space; improving digital skills and ICT adoption across the whole educational system; introducing open educational environment in higher educational institutions on a managerial level; digital educational systems modernization; international quality standards adoption [48].

N. Novolokova divided pedagogical technologies development in world educational space into three phases: first (1920-1960), second (1969-1970), and modern [49]. The scientist thought modern pedagogical technologies originated from pedagogical and technical ideas expressed by pragmatic psychology and pedagogy founders, «industrial pedagogy» representatives. We agree that the technology revolution gives pedagogy a new meaning [48]. However, in the early 21 st century the development of the Internet, mobile communications, cloud technologies, AI development, etc. fundamentally changed the education organization and methods. So we could identify a separate phase in educational technology development from 2010 until now.

At the same time, today it's important to research this new phase in educational technologies development, taking into account rapid society informatization, all spheres of human life digitalization, modern world challenges, and the necessity to react to them.

The research goal is studying and generalization of modern educational technologies; global trends systematization; defining education prospects and threats in the context of society digitalization.

\section{Background}

The educational policy for all levels should be defined to solve the education transformation tasks. However, till now Ukraine does not have a solid document, which regulates public policy on education.

By the «About National education development strategy in Ukraine for the period up to 2021» decree of the President of Ukraine provides for the formation and development of the national education according to modern integration and globalization processes, post-industrial civilization transition requirements. These measures are aimed to achieve sustainable growth and development of Ukraine in the first quarter of the 21st century, national educational system integration in European and world educational space [50]. The Strategy defines the education development priority in modern information and communication technologies adoption, which improves the educational process, education accessibility and efficiency, and prepares youth for life in an information society.

Reflecting on the current challenges Ukrainian and foreign consultants, experts, and NGOs developed the Ukraine Digital Agenda 2020 [51], which defines pivotal digitalization policies, priorities, initiatives, and projects of Ukraine for the 2017-2020 period. The «Ukraine 2030 - the country with developed digital economy» project of The Ukrainian Institute of the Future [52] stated education as one of the basic elements of the (digital) innovation ecosystem and the overall digital economy.

The Ukrainian Institute of the Future's [52] states education as one of the root elements of (digital) innovation ecosystems and the overall digital economy. For education digitalization of Ukraine digital economy and society development concept 2018-2020 [53] provides the following measures: educational resources and digital platforms with interactive and multimedia content support; innovative computer and multimedia educational means and equipment for digital educational environment creation design and implementation. One of the digital competencies of citizens KPIs is for $95 \%$ of the youth from 16 to 20 years old to have basic digital competencies in 10 years, and digital adaptation programs are carried out for citizens older than 50 years before 2030 [52].

It appeared that rapid development and active usage of informational, in particular digital, technologies in all spheres of life require a systematic approach to education system transformation.

\section{Results and discussion}

In recent years experts proposed best practices for education digital transformation $[54,55]$. The measures of digital competencies for citizens (DigComp), educators (DigCompEdu), educational organizations (DigCompOrg), and consumers (DigCOmpConsumers) were developed [56]. The strategy of research directed to research ICT influence on the educational process, and to distinguish several descriptors for modern human digital competencies monitoring and evaluation «Learning and Skills for the Digital Era» was announced [54].

Digital Education Action Plan [57] determines the main priorities of the educational system in the context of rapid digital changes: 
1. Digital technologies adoption for teaching and learning.

2. Digital and digital transformation competencies development.

3. Educational system improvement with Big Data analysis and foresight.

Today the main obstacle for innovation development is a drastic lack of personnel. There are no more than 22,000 professionals with $\mathrm{Ph}$. D. in Artificial Intelligence, and at the same time, there are more than 10,000 open vacancies. In Europe, by 2020 a $20 \%$ increase in time spent using innovative technologies is expected, and a $65 \%$ increase in time spent using basic technological competencies. In the next ten years, $90 \%$ of positions will require digital skills. By 2030 the demand for professionals with social and emotional skills will continue to grow by nearly $22 \%$ in all industrial branches of Europe [58].

To be able to make decisions regarding the prospects of the creation of an educational setting we need to analyze world tendencies. The Organisation for Economic Co-operation and Development (OECD) report 2019 specifies three key trends influencing the outlook of education:

1) globalization;

2) digitalization;

3) population aging.

Under the influence of world globalization processes in the nearest ten years, the middle class will constitute the majority of the world population. This trend will influence providing better education for more people and the satisfaction of more demanding clients. International mobility growth is leading to the necessity of integrating students from different social groups resulting in political and social tensions.

Anticipating education development population aging should be taken into account: in the recent 45 years the average lifespan in OECD countries from 70 to 80 years. It's presumed that the percentage of people older than 65 years will grow.

Older workers will face job market uncertainty, the need for retraining, and advanced training will increase. So mastering the latest technologies requires digital literacy and critical thinking.

At the New Media Consortium initiative, the Horizon project was created about 20 years ago [59, 60]. The project is about emerging teaching and learning technologies aimed to help adopt innovations in educational institutions with expert research and analysis. The expert group from different countries prepares the NMC Horizon Report. Technologies are evaluated according to various criteria, but the main is the potential for teaching, learning, and research in higher education. The experts from 71 countries drawn by the EDUCAUSE association outline the landscape and select the most valuable tendencies forming higher education, teaching, learning, and research. Authors notice that each trend may have a lot of specificities not mentioned in the report depending on higher education institution type, world region, etc. 65\% of the experts represented the USA and 35\% - Australia, China, Egypt, France, Taiwan, and Great Britain. The experts tried to generalize and highlight global trends, but they did not deny the existence of other ones.

In Horizon Report 2020 [60] the experts analyzed and distinguished the key trends forming the future of higher education for the next five years and technological practices influencing education development. The report highlights five key trends groups: social, technological, economic, higher education, and political.

Technological. AI development, next-gen digital learning environment formation, analytics, and privacy questions. AI is already used worldwide as a part of educational services and educational programs. AI adoption increase is foreseen for gathering feedback from students, and as a virtual assistant. Moreover, it may be used for improving access to education for people with visual or hearing impairments. The next-generation digital learning environment (NGDLE) disrupts the way institutions build educational ecosystems for students, and instructors by providing a more flexible and mobile educational process organization and planning. However, higher education institutions should keep privacy standards high, make partnerships carefully, and secure safe data exchange.

Economic. Higher education cost, work, and skills future, climate change. The significance of education as a response to global challenges is assumed to grow. The efficient procreation of knowledge and skills required for life and work as the preeminent task of education should be carried out at a reasonable price. Otherwise, the funding will be decreasing continuously for higher education institutions in many countries.

Higher education. Student population changes, alternative paths to education, online education. The vision of higher education, its goals, and its dominant beneficiaries is continually changing in response to transformation in the human mindset and social, political, and economic relationships. It's crucial to build higher education models and practices adopted for these trends and metamorphosis.

Political. The decrease in higher education funding, higher education value, political polarization. Higher education will continue to influence politics from educational policies and legislation to the political discussions held on campuses.

Social. Well-being and mental health, demographic changes, equity, and fair practices. Well-being and mental health initiatives at universities should help the growing student population with anxiety, depression, and related concerns. A fresh perspective on higher education tasks is vital concerning continuous demographic changes in the global population. The question of education diversity and accessibility remains highly relevant. Figure 1 represents key educational technologies, practices, and challenges.

Ukrainian scientists name common aspiration to various computer tools and ICT (like electronic libraries, handbooks, learning programs, computer-aided testing, simulators) integration in uniting curricular and methodical complexes [61]. These complexes may include elec- 


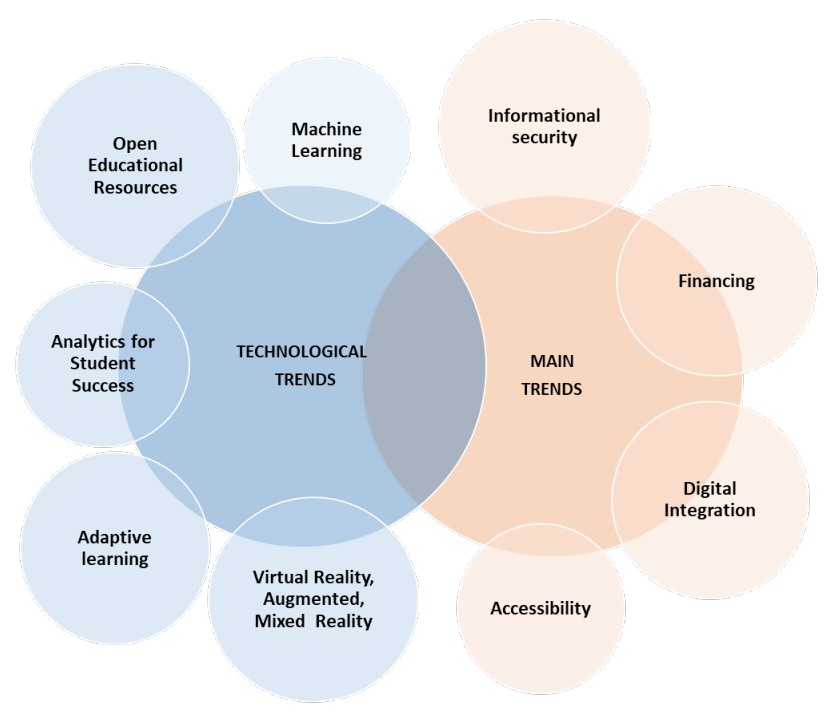

Figure 1. Key educational technologies, practices, and challenges

tronic informational products; digital information materials; software applications; tools and means for creating digital instruments of education; digital learning tools; complex and additional tools; specialized informational Internet resources [61].

Navitas Ventures research projects the traditional educational process to be reconstructed with digital models of education in the nearest 10-15 years, but it appears that transformation is accelerating due to new quarantine challenges.

Table 1 represents the predictions of the educational technologies implementation for the last seven years in the NMC Horizon Report (the time when the technology appears in the report marked in ' $\mathrm{X}$ ').

Horizon-2020 report authors remarked that they stop to forecast some technologies' adoption timeframe due to the fickle COVID-19 crisis, which forced higher education institutions to accommodate in record time and to work with available technologies to be able to provide educational services.

Noone predicted the phenomenal growth of MOOCs for 2020, but there are about 5,490,000,000 results in the Google search engine for the query «online courses».

In Ukraine, the successful cases of EdTech (educational technologies) implementation are the Prometheus MOOCs platform; Preply - educational platform for finding an online tutor; Coursmos - an online micro-learning platform; Highbrow - educational courses email service, etc.

Chatbot helped the applicants with the Application Campaign 2020 on the Ministry of Education and Science of Ukraine website, and some of the higher educational institutions websites, National University of Water and Environmental Engineering in particular. Digital assistant chatbots functionality in the educational space lies not only in answering the frequently asked questions but also in providing students with study materials or promoting discussions. AI allows personalizing the educational process by analyzing the learning curve slope and recommending a personalized learning plan, which improves student academic performance.

Virtual and augmented realities are one more digital educational instrument, which gives the possibility to conduct experiments. Google Play and App Store propose a lot of mobile applications with Augmented Reality, but there is not sufficient content in Ukrainian to hold interactive classes.

According to the anonymous online survey during the first months of the 2020 coronavirus quarantine, the most prevalent tools used in education are Google Meet, email, and specific education platform Moodle with study courses, tasks (figure 2).

The anonymous survey results show near $4 \%$ of students do not engage in remote learning. Technical problems, along with bad Internet connectivity were named as obstacles to remote learning by $69 \%$ of respondentslecturers and $31 \%$ of students. Respondents highlighted the following negative factors of remote learning: low student engagement, live communication absence, increased workload, and extra time for preparation for classes. $76 \%$ of students and $83 \%$ of lecturers wanted to continue remote learning. At the same time, $24 \%$ of students and $17 \%$ of lecturers voted firmly against it.

It came as a conclusion that both students and lecturers are ready to embrace modern educational technologies.

In late 2020, other surveys confirmed our conclusions about the difficulties and opportunities of modern learning, especially in crisis conditions.

2020 EU Public consultation results [63] show:

- almost $60 \%$ of the respondents had not used distance and online learning before the crisis;

- $95 \%$ consider that the COVID-19 crisis marks a point of no return for how technology is used in education and training;

- respondents say that online learning resources and content need to be more relevant, interactive, and easy to use;

- over $60 \%$ felt that they had improved their digital skills during the crisis and more than $50 \%$ of respondents want to do more.

\section{Conclusions and future work}

World higher education is facing unprecedented challenges. Educational institutions work with cutting budgets, and applicant numbers decrease. At the same time, Industry 4.0 requires continuous information technology updates and new educational methods usage. The job market has a great need for professionals with skills in data analytics, cloud computing, artificial intelligence, and machine learning. However, the classical education system has limited capabilities in preparing such specialists.

Key trends force educational institutions to provide more relevant, accessible, and flexible academic programs; to improve online/mixed learning; to split educational programs; to personalize approach to a student. 
Table 1. Educational technologies implementation in the world for the 2012-2019 period (based on Horizon Report 2019 [59])

\begin{tabular}{|c|c|c|c|c|c|c|c|c|}
\hline Educational technologies implementation & 2012 & 2013 & 2014 & 2015 & 2016 & 2017 & 2018 & 2019 \\
\hline Analytics Technologies & $\mathrm{X}$ & $\mathrm{X}$ & $\mathrm{X}$ & & $\mathrm{X}$ & & $\mathrm{X}$ & $\mathrm{X}$ \\
\hline Adaptive Learning Technologies & & & & $\mathrm{X}$ & $\mathrm{X}$ & $\mathrm{X}$ & $\mathrm{X}$ & \\
\hline Games and Gamification & $\mathrm{X}$ & $\mathrm{X}$ & $\mathrm{X}$ & & & & & \\
\hline The Internet of Things & $\mathrm{X}$ & & & $\mathrm{X}$ & & $\mathrm{X}$ & & \\
\hline Mobile Learning & $\mathrm{X}$ & & & & & $\mathrm{X}$ & & $\mathrm{X}$ \\
\hline Natural User Interfaces & $\mathrm{X}$ & & & & & $\mathrm{X}$ & & \\
\hline «Bring Your Own Device» & & & & $\mathrm{X}$ & $\mathrm{X}$ & & & \\
\hline Makerspaces & & & & $\mathrm{X}$ & $\mathrm{X}$ & & $\mathrm{X}$ & \\
\hline Flipped Classroom & & & $\mathrm{X}$ & $\mathrm{X}$ & & & & \\
\hline Wearable Technology & & $\mathrm{X}$ & & $\mathrm{X}$ & & & & \\
\hline 3D-printing & & $\mathrm{X}$ & $\mathrm{X}$ & & & & & \\
\hline Tablet Computing & $\mathrm{X}$ & $\mathrm{X}$ & & & & & & \\
\hline Artificial Intelligence & & & & & & $\mathrm{X}$ & $\mathrm{X}$ & $\mathrm{X}$ \\
\hline Next-Generation LMS & & & & & & $\mathrm{X}$ & & \\
\hline Affective Computing & & & & & $\mathrm{X}$ & & & \\
\hline Mixed Reality & & & & & $\mathrm{X}$ & & $\mathrm{X}$ & $\mathrm{X}$ \\
\hline Robotics & & & & & $\mathrm{X}$ & & $\mathrm{X}$ & \\
\hline Quantified Self & & & $\mathrm{X}$ & & & & & \\
\hline Virtual Assistants & & & $\mathrm{X}$ & & & & & $\mathrm{X}$ \\
\hline Massive Open Online Courses & & $\mathrm{X}$ & & & & & & \\
\hline Blockchain & & & & & & & & $\mathrm{X}$ \\
\hline
\end{tabular}

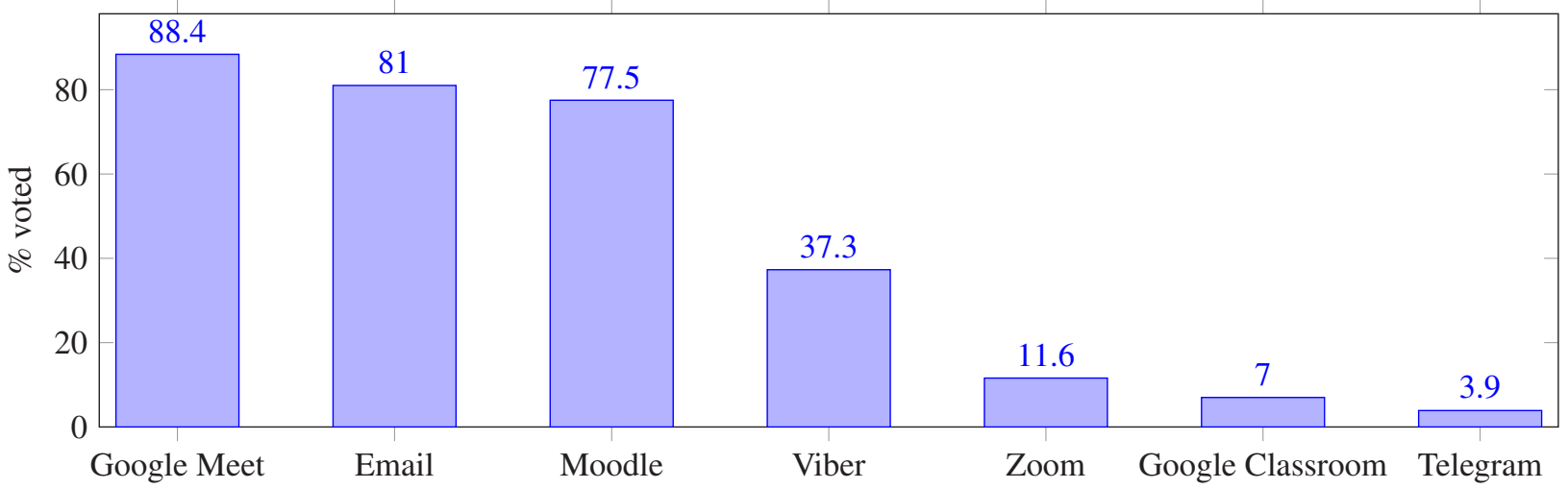

Figure 2. Remote learning tools (based on survey [62])

The response to a challenge is Lifelong Learning development opportunities for teachers, trainers, and other educational staff, new technologies adoption promotion, and improvement of digital skills in education and training. State digitalization strategy requires education adaptation to new requirements. The researches and surveys show that educational workers and students are ready for the changes on their end.

Education, industry, and academy integration remains the main priority. However, Ukrainian educational institutions continue to consume new foreign technologies without producing any.

Higher education institutions practical activity is achieved by various industry internships for students, lecturers, and professors participation in grants and research programs without improving educational institution material and financial base, and creating opportunities for further development of its potential.
We have two likely future scenarios. The first is public support in the creation of innovative research centers. The second is a transition to private educational centers with high fees to be able to update digital technologies, and train or hire professionals. The second scenario also means that quality education will not be affordable for most of the population leading to further state economy recession.

The paradigm that education is an economy serving industry, should be put behind. New challenges drive giving education priority among other spheres since further digital society development depends on highly qualified citizens. Digital technologies force to review the approaches to restricting information, to enable public authorities to use strict measures to information management and control. In our opinion, the contradiction between the need for new technologies and old management control leads to the death of the economy and education relationship as we 
know it. Today there is an urgent need to secure proper education and science financing. Other industries need public authorities control reduction since the control is an elite attempt to preserve old ways of developing and leading.

\section{References}

[1] Global Financial Stability Report, October 2020 (International Monetary Fund, 2020), https://doi . org/10.5089/9781513554228.082

[2] World Economic Outlook, April 2020 (International Monetary Fund, 2020), https://doi.org/10. 5089/9781513539744.081

[3] UNESCO, Charting together for education to \#saveourfuture (2020), https://en.unesco.org/news/ charting-together-education-saveourfuture

[4] E.U. von Weizsäcker, A. Wijkman, Come On! Capitalism, Short-termism, Population and the Destruction of the Planet. A Report to the Club of Rome (Springer New York, 2018), https://doi.org/ 10. $1007 / 978-1-4939-7419-1$

[5] S.O. Semerikov, I.O. Teplytskyi, V.N. Soloviev, V.A. Hamaniuk, N.S. Ponomareva, O.H. Kolgatin, L.S. Kolgatina, T.V. Byelyavtseva, S.M. Amelina, R.O. Tarasenko, Journal of Physics: Conference Series 1840, 012036 (2021)

[6] Cabinet of Ministers of Ukraine, The development concept of the digital economy and society of ukraine for 2018-2020. order no. 67p. (2018), https://zakon.rada.gov.ua/laws/ show/67-2018- $\%$ D $1 \backslash \% 80 \backslash \#$ Text

[7] E. Fedorenko, V. Velychko, A. Stopkin, A. Chorna, V. Soloviev, CEUR Workshop Proceedings 2433, 20 (2019)

[8] Y. Kazhan, V. Hamaniuk, S. Amelina, R. Tarasenko, S. Tolmachev, CEUR Workshop Proceedings 2643, 392 (2020)

[9] O. Bondarenko, O. Pakhomova, W. Lewoniewski, CEUR Workshop Proceedings 2547, 13 (2020)

[10] O. Burov, A. Kiv, S. Semerikov, A. Striuk, M. Striuk, L. Kolgatina, I. Oliinyk, CEUR Workshop Proceedings 2731, 1 (2020)

[11] O. Burov, V. Bykov, S. Lytvynova, CEUR Workshop Proceedings 2732, 583 (2020)

[12] O. Glazunova, T. Voloshyna, A. Gurzhii, V. Korolchuk, O. Parhomenko, T. Sayapina, T. Semyhinivska, CEUR Workshop Proceedings 2732, 591 (2020)

[13] A. Kiv, V. Soloviev, S. Semerikov, CEUR Workshop Proceedings 2433, 1 (2019)

[14] V. Tkachuk, Y. Yechkalo, S. Semerikov, M. Kislova, V. Khotskina, CEUR Workshop Proceedings 2732, 1217 (2020)

[15] T. Kramarenko, O. Pylypenko, V. Zaselskiy, CEUR Workshop Proceedings 2547, 130 (2020)

[16] O. Lavrentieva, I. Arkhypov, O. Kuchma, A. Uchitel, CEUR Workshop Proceedings 2547, 201 (2020)
[17] O. Markova, S. Semerikov, M. Popel, CEUR Workshop Proceedings 2104, 388 (2018)

[18] I. Mintii, V. Soloviev, CEUR Workshop Proceedings 2257, 227 (2018)

[19] Y. Modlo, S. Semerikov, P. Nechypurenko, S. Bondarevskyi, O. Bondarevska, S. Tolmachev, CEUR Workshop Proceedings 2433, 413 (2019)

[20] M. Moiseienko, N. Moiseienko, I. Kohut, A. Kiv, CEUR Workshop Proceedings 2643, 60 (2020)

[21] N. Morze, O. Buinytska, O. Glazunova, O. Kuzminska, G. Protsenko, I. Vorotnykova, CEUR Workshop Proceedings 1844, 229 (2017)

[22] Y. Modlo, S. Semerikov, S. Bondarevskyi, S. Tolmachev, O. Markova, P. Nechypurenko, CEUR Workshop Proceedings 2547, 217 (2020)

[23] K. Osadcha, V. Osadchyi, S. Semerikov, H. Chemerys, A. Chorna, CEUR Workshop Proceedings 2732, 547 (2020)

[24] N. Rashevska, V. Soloviev, CEUR Workshop Proceedings 2257, 192 (2018)

[25] Y. Modlo, S. Semerikov, E. Shmeltzer, CEUR Workshop Proceedings 2257, 148 (2018)

[26] P. Merzlykin, M. Popel, S. Shokaliuk, CEUR Workshop Proceedings 2168, 13 (2017)

[27] M. Popel, S. Shokalyuk, M. Shyshkina, CEUR Workshop Proceedings 1844, 327 (2017)

[28] S. Semerikov, I. Teplytskyi, Y. Yechkalo, O. Markova, V. Soloviev, A. Kiv, CEUR Workshop Proceedings 2393, 833 (2019)

[29] T.A. Vakaliuk, O.M. Spirin, N.M. Lobanchykova, L.A. Martseva, I.V. Novitska, V.V. Kontsedailo, Journal of Physics: Conference Series 1840, 012051 (2021)

[30] A. Striuk, M. Rassovytska, S. Shokaliuk, CEUR Workshop Proceedings 2104, 412 (2018)

[31] S. Symonenko, V. Osadchyi, S. Sysoieva, K. Osadcha, A. Azaryan, CEUR Workshop Proceedings 2643, 225 (2020)

[32] S. Semerikov, I. Teplytskyi, Y. Yechkalo, A. Kiv, CEUR Workshop Proceedings 2257, 122 (2018)

[33] N. Rashevska, S. Semerikov, N. Zinonos, V. Tkachuk, M. Shyshkina, CEUR Workshop Proceedings 2731, 79 (2020)

[34] T. Vakaliuk, V. Kontsedailo, D. Antoniuk, O. Korotun, I. Mintii, A. Pikilnyak, CEUR Workshop Proceedings 2547, 66 (2020)

[35] K. Vlasenko, O. Chumak, I. Lovianova, D. Kovalenko, N. Volkova, E3S Web of Conferences 166, 10011 (2020)

[36] A. Tokarieva, N. Volkova, I. Harkusha, V. Soloviev, CEUR Workshop Proceedings 2433, 74 (2019)

[37] O. Yankovych, V. Chaika, T. Ivanova, K. Binytska, I. Kuzma, O. Pysarchuk, H. Falfushynska, CEUR Workshop Proceedings 2433, 126 (2019)

[38] A. Kiv, M. Shyshkina, S. Semerikov, A. Striuk, Y. Yechkalo, CEUR Workshop Proceedings 2547, 1 (2020)

[39] L. Burkova, Ridna shkola 2, 18 (2001) 
[40] O. Yankovych, Y. Bednarek, A. Andzheyevska, Modern educational institutions technologies: training manual, Ternopil (2015)

[41] O. Yankovych, Educational technologies in the history of higher pedagogical education in Ukraine 1957-2008 (Pidruchnyky i posibnyky, Ternopil, 2008)

[42] O. Topuzov, O. Malykhin, T. Yarmolchuk, Informational technologies in education 3, 205 (2020)

[43] G. Kovalchuk, Education intensification in economics education (KNEU, Kyiv, 2003)

[44] V. Bykov, Informational technologies in education 17, 9 (2013)

[45] M.Y. Kademiya, Theory and practice of social systems management 2 (2014)

[46] M. Kademiya, Informational communicational technologies in education: the glossary of terms (SPOLOM, Lviv, 2009)

[47] I. Dychkivska, Innovation pedagogical technologies (Academvudav, Kyiv, 2004)

[48] O. Tovkanets, Informational technologies in education 4, 14 (2018)

[49] N. Novolokova, Pedagogical and innovation encyclopedia (Osnova, Kharkiv, 2012)

[50] President of Ukraine, About national strategy of education development in ukraine for the period up to 2021. order no. 344/2013 (2013), http://zakon4. rada.gov.ua/laws/show/344/2013

[51] Ukraine Digital Agenda - 2020. Conceptual basis (2016), https://ucci.org.ua/uploads/files/ 58e78ee3c3922.pdf

[52] Ukraine 2030e - the country with a developed digital economy, https: //strategy.uifuture.org/ ukraina-learning-nation.html

[53] Cabinet of Ministers of Ukraine, About the approval of the concept of the digital economy and society development of ukraine for 2018 - 2020, and approval of the action plan for its implementation. order no. 67-p. (2018), https://zakon . rada.gov. ua/laws/show/67-2018-\%D1\%80\#Text

[54] EU SCIENCE HUB, Learning and skills for the digital era (2020), https://ec . europa.eu/jrc/en/ research-topic/learning-and-skills
[55] Council recommendation on key competences for lifelong learning (2018), https://eur-lex. europa.eu/legal-content/EN/TXT/?uri= uriserv\%3A0].C_.2018.189.01.0001.01.ENG\& amp; toc $=0$ J\%3AC\%3A2018\%3A189\%3ATOC

[56] O. Kuzminska, M. Mazorchuk, N. Morze, V. Pavlenko, A. Prokhorov, CEUR Workshop Proceedings 2104, 366 (2018)

[57] Commission digital education action plan (2018), https://ec.europa.eu/ education/education-in-the-eu/ digital-education-action-plan_en/

[58] Trends Shaping Education 2019 (OECD, 2019), https://doi.org/10.1787/trends_ edu-2019-en

[59] B. Alexander, K. Ashford-Rowe, N. BarajasMurphy, G. Dobbin, J. Knott, M. McCormack, J. Pomerantz, R. Seilhamer, N. Weber, eds., EDUCAUSE Horizon Report: 2019 Higher Education Edition (EDUCAUSE, 282 Century Place, Suite 5000 Louisville, CO 80027, 2019), ISBN 978-1-933046-02-0, https: //library.educause.edu/-/media/files/ library/2019/4/2019horizonreport.pdf

[60] M. Brown, M. McCormack, J. Reeves, D.C. Brooks, S. Grajek, B. Alexander, M. Bali, S. Bulger, S. Dark, N. Engelbert et al., eds., 2020 EDUCAUSE Horizon Report. Teaching and Learning Edition (EDUCAUSE, 282 Century Place, Suite 5000 Louisville, CO 80027, 2020), ISBN 978-1-933046-03-7, https: //library.educause.edu/-/media/files/ library/2020/3/2020horizonreport.pdf

[61] M. Mykhailichenko, Y. Rudyk, Educational technologies: a training manual, Kyiv (2016)

[62] The results of the anonymous online survey about distance learning in nuwee among scientific and pedagogical workers (2020), https://nuwm. edu.ua/ sp/opituvannja

[63] Commission digital education action plan (2021-2027), https://ec.europa.eu/ education/education-in-the-eu/ digital-education-action-plan_en 